Proceeding Paper

\title{
The Bayankhongor Metal Belt (Mongolia): Constraints on Crustal Architecture and Implications for Mineral Emplacement from 3-D Electrical Resistivity Models ${ }^{\dagger}$
}

\author{
Matthew J. Comeau 1,* , Michael Becken ${ }^{1}$, Alexey V. Kuvshinov ${ }^{2}$, Sodnomsambuu Demberel ${ }^{3}$, \\ Erdenechimeg Batmagnai ${ }^{2}$ and Shoovdor Tserendug ${ }^{3}$
}

Citation: Comeau, M.J.; Becken, M.; Kuvshinov, A.V.; Demberel, S.; Batmagnai, E.; Tserendug, S. The Bayankhongor Metal Belt (Mongolia): Constraints on Crustal Architecture and Implications for Mineral Emplacement from 3-D Electrical Resistivity Models. Environ. Sci. Proc. 2021, 6, 32. https:// doi.org/10.3390/iecms2021-09360

Academic Editor: Paul Sylvester

Published: 25 February 2021

Publisher's Note: MDPI stays neutral with regard to jurisdictional claims in published maps and institutional affiliations.

Copyright: $\left({ }^{\circ} 2021\right.$ by the authors. Licensee MDPI, Basel, Switzerland. This article is an open access article distributed under the terms and conditions of the Creative Commons Attribution (CC BY) license (http://creativecommons.org/licenses/by/4.0/).
Institut für Geophysik, Universität Münster, Correnstrasse 24, 48149 Münster, Germany; michael.becken@uni-muenster.de

2 Institute of Geophysics, Swiss Federal Institute of Technology (ETH), Sonneggstrasse 5, 8092 Zürich, Switzerland; kuvshinov@erdw.ethz.ch (A.V.K.); erdenechimeg@erdw.ethz.ch (E.B.)

3 Institute of Astronomy \& Geophysics, Mongolian Academy of Sciences, P.O. Box 152, Ulaanbaatar 13343, Mongolia; demberel@iag.ac.mn (S.D.); tserendug@iag.ac.mn (S.T.)

* Correspondence: matthew.comeau@uni-muenster.de

† Presented at the 2nd International Electronic Conference on Mineral Science, 1-15 March 2021; Available online: https://iecms2021.sciforum.net/.

\begin{abstract}
The Bayankhongor Metal Belt, a metallogenic belt that extends for more than $100 \mathrm{~km}$ in central Mongolia, is an economically significant zone that includes sources of gold and copper. Unfortunately, the crustal architecture is poorly understood throughout this region. However, it is known that the crustal structure strongly influences the development and emplacement of mineral zones. Electrical resistivity is a key physical parameter for mineral exploration that can help to locate mineral zones and determine the regional crustal structure. We use naturalsource magnetotelluric data to generate three-dimensional electrical resistivity models of the crust. The results show that anomalous, low-resistivity zones in the upper crust are spatially associated with the surface expressions of known mineral occurrences, deposits, and mining projects. We thus infer that the development of the mineralization is closely linked to the lowresistivity signatures and, therefore, to crustal structures, due primarily to their influence on fluid flow. The low-resistivity signatures are possibly related to associated sulfide mineralogy within the host complex and to structures and weaknesses that facilitated fluid movement and contain traces of past hydrothermal alteration. Thus, the crustal architecture, including major crustal boundaries that influence fluid distribution, exerts a first-order control on the location of the metallogenic belt. By combining our electrical resistivity results with other geological and petrological data, we attempt to gain insights into the emplacement and origin of mineral resources.
\end{abstract}

Keywords: metallogenic belt; ophiolite belt; suture zone; mineralization; mineral emplacement; mineral genesis; mineral exploration; electrical resistivity; magnetotellurics; 3-D inversion

\section{Introduction}

The mineral systems concept, whereby mineralized zones are seen as small expressions of a range of Earth processes, is recognized as the key to targeting new deposits and to interpreting ore genesis, through understanding the organizational framework of the system [1]. Links between the location of mineralized zones and their underlying crustal structure have been established for many well-known mineral districts [2]. Further- 
more, it has been recognized that major crustal boundaries may be important in the formation of mineralized zones, and that their internal geometry is inherited from earlier tectonic features [3].

A large suture zone in central Mongolia, at the southern margin of the Hangai mountains within the Central Asian Orogenic Belt, is marked by the Bayankhongor Ophiolite Belt $[4,5]$. This gives evidence for the closure of a paleo-ocean and is believed to represent a major crustal boundary. In addition, adjacent fault segments are believed to be part of the reactivated South Hangai fault system [6]. Immediately to the south of the suture zone, metamorphic and volcanic provinces are identified [7]. Distributed throughout this region are occurrences of gold and copper mineralization [8,9], which make up the Bayankhongor Metal Belt (Figure 1).

Many questions remain about the near-surface framework and crustal structure of these mineral zones. In addition, knowledge of their vertical extent, and possible connection to deeper sources, can provide insights into their formation and development. In this presentation, we analyze three- dimensional (3-D) electrical resistivity models generated from magnetotelluric (MT) measurements and investigate the geometry and extent of the features beneath the metallogenic belt and the adjacent suture zone and ophiolite belt.

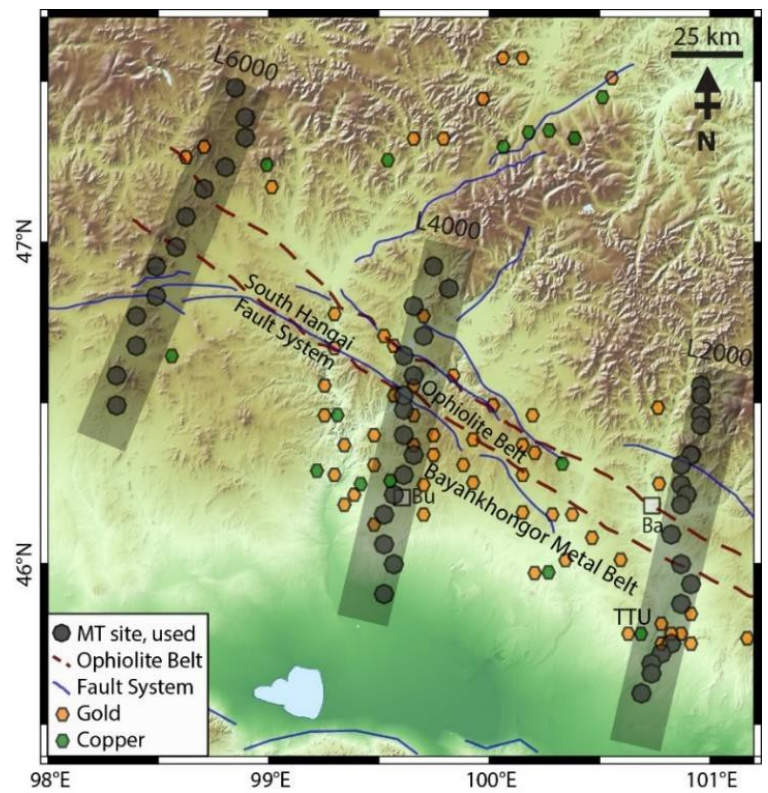

Figure 1. Map of the study area indicating locations of MT measurement sites and profiles. The approximate location of the Bayankhongor Ophiolite Belt and faults are marked. This region contains many mineralized zones, which make up the Bayankhongor Metal Belt, that contain significant occurrences of copper and gold. Villages: $\mathrm{Bu}=$ Bumbugur; $\mathrm{Ba}=$ Bayankhongor.

\section{Method}

The MT method is a geophysical technique used to probe the subsurface electrical structure of the Earth using passive electromagnetic signals. It is especially sensitive to the quantity and composition of crustal fluids, which act to reduce the electrical resistivity. For this reason, numerous studies have shown that the MT method is ideally suited to image the structure of faults and suture zones at various scales. In addition, it is capable of characterizing the pathways of past fluids and the ancient traces of alteration, and this has been used to explore the formation and emplacement of mineral ore deposits [2].

An extensive MT dataset exists across Mongolia with several resistivity models produced, which investigate multiple features and scales [10-14]. Previous studies have explored the lithospheric-scale regional structure below central Mongolia and have revealed upper-most mantle low-resistivity anomalies attributed to an asthenospheric 
upwelling [10,11]. The lower crust was also established to have a low-resistivity and was inferred to be a weak, low viscosity region $[10,13]$. Other work investigated lithospheric removal mechanisms, supported by geochemical data $[15,16]$. We analyze three profile segments in the Bayankhongor region, in which MT data were inverted with the MODEM inversion algorithm $[17,18]$ (for details of the inversion procedure and model testing, please refer to [19]).

\section{Results}

The 3-D resistivity models (Figure 2) show that, in general, the upper crust appears highly resistive (>1000 $\Omega \mathrm{m} ; \mathrm{R} 1, \mathrm{R} 2$, and R3). This can be explained by ancient microcontinental blocks [4]. The middle crust appears to have a much lower resistivity $(<300 \Omega \mathrm{m})$. The most obvious features are the low-resistivity anomalies $(<100 \Omega \mathrm{m})$. An isolated lowresistivity anomaly ( $<30 \Omega \mathrm{m}$; M1) appears beneath the eastern end of the Bayankhongor Metal Belt, near the Tsagaan Tsahir Uul and Saran Uul regions that include gold and copper deposits $[9,20]$. This area is described as a Proterozoic metamorphic unit with granites [20]. Similarly, a low-resistivity feature $(<30 \Omega \mathrm{m}$; M2) appears beneath the Bayankhongor Metal Belt near the village of Bumbugur. This area is described as a highly metamorphosed unit [5,7]. The (inferred) location of the Bayankhongor Ophiolite Belt $[4,5,7]$ is congruent with low-resistivity anomalies $(<50 \Omega \mathrm{m}$; S1, S2, and S3) that appear to be dipping slightly southwards, consistent with geological estimates [5,7]. Other low-resistivity features (U1 and $\mathrm{U} 2$ ) are observed that do not reach the surface.

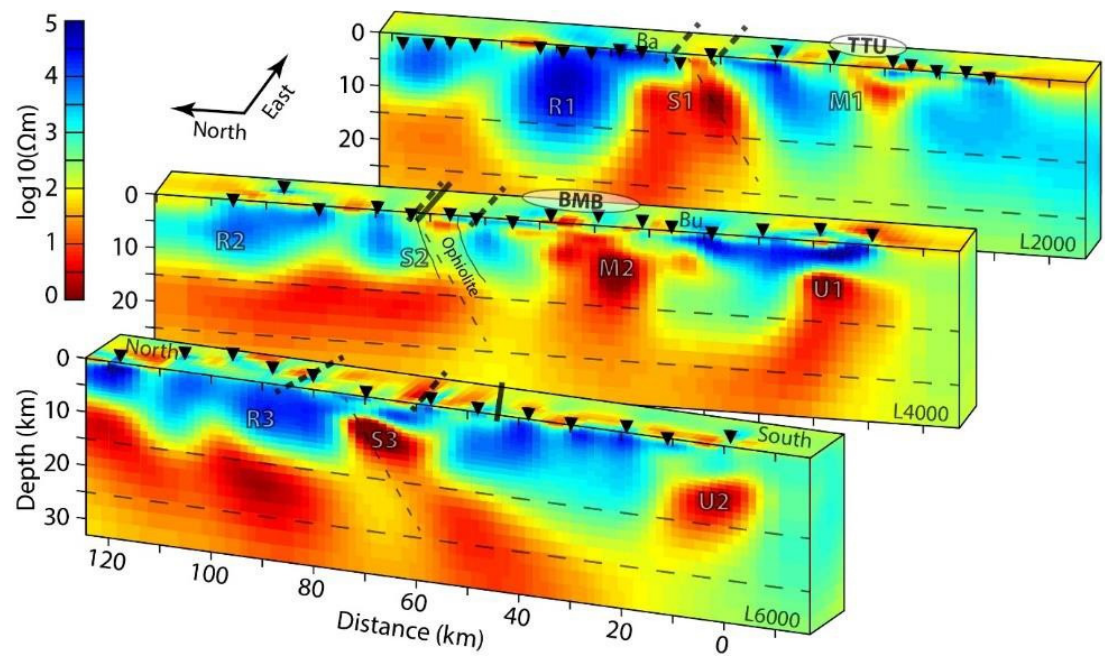

Figure 2. The 3-D electrical resistivity models. MT measurement sites are marked. The Bayankhongor Ophiolite Belt (dashed surface lines) and the South Hangai fault system (solid lines) are related to a suture zone, revealed to be a major boundary (dashed). Low-resistivity anomalies in the upper crust appear coincident with the boundary (S1; S2; S3). Mineralized zones (BMB: Bayankhongor Metal Belt; TTU: Tsagaan Tsahir Uul and Saran Uul) are coincident with low- resistivity anomalies in the upper crust (M1; M2). Highly resistive features are attributed to an ancient continental block (R1; R2; R3). Other low-resistivity anomalies (U1; U2) are observed in the south.

\section{Discussion}

The spatial distribution of mineral zones is known to be strongly influenced by the crustal architecture, which has an impact on the flow of fluids through the crust (i.e., permeability is structurally enhanced). In turn, crustal structure is partly controlled by tectonic and geodynamic processes. Thus, the crustal features imaged with geophysical models (e.g., resistivity models), can give insights into the emplacement of mineral systems. In addition, geophysical gradients can strongly highlight crustal boundaries [21].

The electrical resistivity models show that some low-resistivity anomalies align with the suture zone and that they extend to great depths. Thus, the results show that the ancient 
suture zone, marked by the Bayankhongor Ophiolite Belt and associated with a paleoocean closure, is a deep-reaching structure (crustal or lithospheric scale) and a major crustal boundary [19]. The low-resistivity anomalies may be explained by hydrothermal alteration along fossil fluid pathways, which the MT method is sensitive enough to detect. These fluids may have been sourced through metamorphic dehydration reactions in the crust, and their upwards propagation was controlled by the local permeability within the deformation zone, such as weaknesses that facilitated fluid movement [22].

The locations of other low-resistivity anomalies are spatially coincident with known mineralized zones in the Bayankhongor Metal Belt, which contains copper and gold deposits $[5,7,20]$. Throughout the area there is evidence of extensive hydrothermal alteration $[5,9,20]$ and dikes [20], which are often both spatially and temporally correlated with gold mineralization [3]. They were likely formed by fluid flow through the crust during metamorphism and indicate deeply-connected, ore-forming fluid pathways [3]. The observed low-resistivity signature may be explained by hydrothermal alteration along fossil fluid pathways and associated sulfide mineralogy within the host complex related to ore emplacement [19].

We hypothesize that the emplacement of the minerals within the Bayankhongor Metal Belt is directly connected to the unique and complex tectonic history of the Bayankhongor region. We conclude that the results illustrate that crustal architecture, specifically major crustal boundaries (including crustal/lithospheric scale suture zones) that are inherited from earlier tectonic events, acts as a first-order control on the location of mineral deposits and metallogenic belts, due to its influence on the availability and mobility of (ore-related) fluid.

\section{Institutional Review Board Statement: Not applicable.}

Informed Consent Statement: Not applicable.

Data Availability Statement: The MT data are archived by the German Research Centre for Geosciences (GFZ) Potsdam, for technical details see reports by Becken et al. [23,24].

\section{References}

1. Davies, S.; Groves, D.I.; Trench, A.; Dentith, M. Towards producing mineral resource-potential maps within a mineral systems framework, with emphasis on Australian orogenic gold systems. Ore Geol. Rev. 2020, 119, 103369, doi:10.1016/j.oregeorev.2020.103369.

2. Heinson, G.S.; Direen, N.G.; Gill, R.M. Magnetotelluric evidence for a deep-crustal mineralizing system beneath the Olympic Dam iron oxide copper-gold deposit, southern Australia. Geology 2006, 34, 573-576, doi:10.1130/G22222.1.

3. Groves, D.I.; Santosh, M.; Goldfarb, R.J.; Zhang, L. Structural geometry of orogenic gold deposits: Implications for exploration of world-class and giant deposits. Geosci. Front. 2018, 9, 1163-1177, doi:10.1016/j.gsf.2018.01.006.

4. Badarch, G.; Cunningham, W.D.; Windley, B.F. A new subdivision for Mongolia: Implications for the Phanerozoic crustal growth of Central Asia. J. Asian Earth Sci. 2002, 21, 87-110, doi:10.1016/S1367-9120(02)00017-2.

5. Buchan, C.; Cunningham, D.; Windley, B.F.; Tomurhuu, D. Structural and lithological characteristics of the Bayankhongor Ophiolite Zone, Central Mongolia. J. Geol. Soc. 2001, 158, 445-460, doi:10.1144/jgs.158.3.445.

6. Walker, R.T.; Nissen, E.; Molor, E.; Bayasgalan, A. Reinterpretation of the active faulting in central Mongolia. Geology 2007, 35, 759-762, doi:10.1130/G23716A.1.

7. Osozawaa, S.; Tsolmon, G.; Majigsuren, U.; Sereenen, J.; Niitsuma, S.; Iwata, N.; Pavlis, T.; Jahn, B. Structural evolution of the Bayanhongor region, west-central Mongolia. J. Asian Earth Sci. 2008, 33, 337-352, doi:10.1016/j.jseaes.2008.01.003.

8. Gerel, O.; Pirajno, F.; Batkhishig, B.; Dosta, J. Mineral Resources of Mongolia, Modern Approaches in Solid Earth Sciences; Springer: Singapore, 2021, doi:10.1007/978-981-15-5943-3.

9. Watanabe, J.; Turmagnai, D.; Byambasuren, D.; Oyunchimeg, G.; Tsedenbaljir, Y.; Sato, Y. Geology and K-Ar Ages of the South, Huh Bulgiin Hundii, Saran Uul, Taats Gol and Han Uul deposits in the Bayankhongor Region, Mongolia. Resour. Geol. 1999, 49, 123-130, doi:10.1111/j.1751-3928.1999.tb00038.x.

10. Comeau, M.J.; Käufl, J.S.; Becken, M.; Kuvshinov, A.V.; Grayver, A.V.; Kamm, J.; Demberel, S.; Sukhbaatar, U.; Batmagnai, E. Evidence for fluid and melt generation in response to an asthenospheric upwelling beneath the Hangai Dome, Mongolia. Earth Planet. Sci. Lett. 2018, 487, 201-209, doi:10.1016/j.epsl.2018.02.007.

11. Käufl, J.S.; Grayver, A.V.; Comeau, M.J.; Kuvshinov, A.V.; Becken, M.; Batmagnai, E.; Demberel, S. Magnetotelluric multiscale 3-D inversion reveals crustal and upper mantle structure beneath the Hangai and Gobi-Altai region in Mongolia. Geophys. J. Int. 2020, 221, 1002-1028, doi:10.1093/gji/ggaa039. 
12. Comeau, M.J.; Becken, M.; Käufl, J.S.; Grayver, A.V.; Kuvshinov, A.V.; Tserendug, S.; Batmagnai, E.; Demberel, S. Evidence for terrane boundaries and suture zones across Southern Mongolia detected with a 2-dimensional magnetotelluric transect. Earth Planets Space 2020, 72, doi:10.1186/s40623-020-1131-6.

13. Comeau, M.J.; Becken, M.; Connolly, J.A.D.; Grayver, A.V.; Kuvshinov, A.V. Compaction-driven fluid localization as an explanation for lower crustal electrical conductors in an intracontinental setting. Geophys. Res. Lett. 2020, 47, doi:10.1029/2020GL088455.

14. Comeau, M.J.; Becken, M.; Käufl, J.S.; Kuvshinov, A.V.; Demberel, S. Images of intraplate volcanism: The upper crustal structure below Tariat volcanic zone, Mongolia, imaged with magnetotellurics. In Proceedings of the EGU General Assembly, Vienna, Austria, 8-13 April 2018.

15. Becker, F.; Stein, C.; Comeau, M.J.; Becken, M.; Hansen, U. Modelling delamination as a process of lithosphere thinning determined by magnetotelluric measurements. In Proceedings of the 28th Schmucker-Weidelt Colloquium for Electromagnetic Depth Research, Haltern am See, Germany, 23-27 September 2019.

16. Comeau, M.J.; Stein, C.; Becken, M.; Hansen, U. Geodynamic Modeling of Lithospheric Removal and Surface Deformation: Application to Intraplate Uplift in Central Mongolia. J. Geophys. Res. Solid Earth 2021, 126, doi:10.1029/2020JB021304.

17. Kelbert, A.; Meqbel, N.; Egbert, G.D.; Tandon, K. ModEM: A modular system for inversion of 854 electromagnetic geophysical data. Comput. Geosci. 2014, 66, 40-53, doi:10.1016/j.cageo.2014.01.010.

18. Egbert, G.D.; Kelbert, A. Computational Recipes for Electromagnetic Inverse Problem. Geophys. J. Int. 2012, 189, 251-267, doi:10.1111/j.1365-246X.2011.05347.x.

19. Comeau, M.J.; Becken, M.; Kuvshinov, A.; Demberel, S. Crustal architecture of a metallogenic belt and ophiolite belt: Implications for mineral genesis and emplacement from 3-D electrical resistivity models (Bayankhongor area, Mongolia). Earth Planets Space 2021, 73, doi:10.1186/s40623-021-01400-9.

20. Jargalan, S.; Fujimaki, H.; Ohba, T. Petrologic characteristics and Rb-Sr age dating of lamprophyte dikes of Tsagaan Tsahir Uul gold deposit, Mongolia. J. Mineral. Petrol. Sci. 2007, 102, 163-173, doi:10.2465/jmps.060322b.

21. Motta, J.G.; Betts, P.G.; de Souza Filho, C.R.; Thiel, S.; Curtis, S.; Armit, R.J. Proxies for Basement Structure and Its Implications for Mesoproterozoic Metallogenic Provinces in the Gawler Craton. J. Geophys. Res. Solid Earth 2019, 124, 3088-3104, doi:10.1029/2018JB016829.

22. Drummond, B.J.; Hobbs, B.E.; Goleby, B.R. The role of crustal fluids in the tectonic evolution of the Eastern Goldfields Province of the Archaean Yilgarn Craton, Western Australia. Earth Planets Space 2004, 56, 1163-1169, doi:10.1186/BF03353335.

23. Becken, M.; Kuvshinov, A.V.; Comeau, M.J.; Käufl, J. Magnetotelluric Study of the Hangai Dome, Mongolia. GFZ Data Serv. 2021, doi:10.5880/GIPP-MT.201613.1.

24. Becken, M.; Kuvshinov, A.V.; Comeau, M.J.; Käufl, J. Magnetotelluric Study of the Hangai Dome, Mongolia: Phase II. GFZ Data Serv. 2021, doi:10.5880/GIPP-MT.201706.1. 